\title{
Geographic Information Systems supported by multi-criteria decision analysis to indicate potentially suitable areas for construction and demolition waste disposal
}

Uso do SIG auxiliado pela análise multicritério de tomada de decisão na indicação de possíveis áreas aptas para a disposição em solo de resíduos de construção civil Barbara Pavani Biju ${ }^{1}$ (), André Nagalli² (D), Edilberto Nunes de Moura ${ }^{3}$ (1)

\section{A B S T RAC T}

In Brazil, the disposal of construction and demolition waste (CDW) quite often occurs in inadequate places, resulting in social, economic, and environmental problems. This reflects the need for selecting appropriate areas for the disposal of this type of waste. These areas must follow local standards and regulations to protect human health and the environment. Considering that, this study is intended to indicate potentially suitable areas for CDW landfill deployment, known as Class A landfill in Brazil, supported by a GIS-MCDA based model. The GIS-MCDA technique, used as a basic tool to identify potentially suitable areas, has several advantages, such as low cost, reduced spatial data subjectivity, and fast decision-making process. The place chosen for this study is the Urban Central Core of the Metropolitan Area of Curitiba. By integrating GIS with MCDA techniques in this research study, it was possible to indicate potentially suitable areas for CDW disposal in this region.

Keywords: construction and demolition waste; waste management; environmental planning; environmental protection; landfill.

\section{RE S U M O}

No Brasil, a disposição dos resíduos de construção e demolição é frequentemente efetuada em locais inapropriados, resultando em problemas sociais, econômicos e ambientais, o que demonstra a necessidade de áreas aptas para a sua correta disposição final. A área adequada deve estar de acordo com as regulações e normas locais. Considerados esses fatos, o objetivo do presente trabalho é indicar possíveis áreas aptas para a construção de um aterro classe $A$, apoiado por um modelo baseado em SIG-MCDA. O SIG-MCDA, que é utilizado na identificação de possíveis áreas aptas, apresenta diversas vantagens: baixo custo, redução da subjetividade do dado espacial e processo de tomada de decisão mais ágil. O local de estudo escolhido foi o Núcleo Urbano Central de Curitiba. A integração do SIG com as técnicas de MCDA nesta pesquisa resultou na indicação de possíveis áreas adequadas para o descarte dos resíduos de construção de demolição para essa região.

Palavras-chave: resíduos de construção e demolição; gerenciamento de resíduos; planejamento ambiental; proteção ambiental; aterros sanitários.

\footnotetext{
${ }^{1}$ Faculdade de Ciências, Universidade do Porto - Porto, Portugal.

${ }^{2}$ Universidade Tecnológica Federal do Paraná - Curitiba (PR), Brazil.

${ }^{3}$ Pontifícia Universidade Católica do Paraná - Curitiba (PR), Brazil.

Correspondence address: André Nagalli - Rua Deputado Alencar Furtado, 5000 - Campo Comprido - CEP: 81280-340 - Curitiba (PR), Brazil.

E-mail: nagalli@utfpr.edu.br

Conflicts of interest: the authors declare that there are no conflicts of interest.

Funding: Coordination for the Improvement of Higher Education Personnel (CAPES).
}

Received on: 10/18/2020. Accepted on: 06/10/2021.

https://doi.org/10.5327/Z21769478947

This is an open access article distributed under the terms of the Creative Commons license. 


\section{Introduction}

The illegal disposal of construction and demolition waste in Brazil is considered a matter of public concern and may result in several disadvantages for society as a whole, such as high costs for public drainage and health systems, because waste sedimentation may increase the chances of flooding, contributing to soil and surface water contamination and obstruction of urban drainage systems (Ferreira and Pinto, 2010; Pinheiro et al., 2019). Among the various approaches developed for municipal solid waste management, landfills continue to be the main final destination of waste (Costa and Silva, 2011). When properly segregated, construction and demolition waste (CDW) in Brazil is deployed as construction and inert waste in landfills (ABNT, 2004).

When selecting CDW disposal sites, it is extremely important to adopt a prevention policy to ensure environmental integrity and the well-being of the population. Site selection requires the collection and processing of a wide range of information on environmental aspects, socioeconomic status, and operational location. In addition, it should consider the interaction between planning and waste management (Geneletti, 2010). Moreover, the criteria established and used to indicate potentially suitable sites for landfill construction need to be technically defined and analyzed. This is a complex process because its evaluation requires time devoted by the parties involved. In addition, it is an expensive decision-making process since it involves different criteria for site selection (Rikalovic et al., 2014).

It is important to consider other methods that accelerate and minimize the costs of area selection. For example, we can mention the Geographic Information System (GIS) and Multi-Criteria Decision Analysis (MCDA) techniques. This combination has been widely used in site selection and urban planning studies, as mentioned by Ramos (2000), Dalmas et al. (2011) and Geus et al. (2019). Regarding spatial analysis, several decision-making problems give rise to the MCDA technique combined with GIS (Boroushaki and Malczewski, 2008). Contribution and research progress in terms of integration between GIS and MCDA derives from the synergy between these two distinct sets of decision-support tools. GIS technique can improve MCDA capabilities by exploring the decision situation and supporting the learning and discovery process, while MCDA integration into the GIS can improve GIS limited capabilities in data storage and analysis, according to the decision maker's preference (Malczewski and Rinner, 2015). This technique has been useful to indicate suitable areas to receive different types of developments, when different criteria are related to the decision-making process (Demesouka et al., 2013; Koc-San et al., 2013).

Therefore, this study is intended to indicate potentially suitable areas for the disposal of CDW in the Urban Central Core of the Metropolitan Area of Curitiba, using Spatial Analysis tools in a Geographic Information System environment, supported by the MCDA technique and pre-established criteria. GIS-MCDA integration has never been used to manage $\mathrm{CDW}$ in this region and can contribute to decision-making processes in waste management. Thus, it can help protect human and environmental health, considering Brazil's current CDW standards and applicable specific legislation.

\section{Material and Methods}

Several methods can be adopted for the selection of landfills. In this study, GIS software known as $\operatorname{ArcGIS}^{\circledR}$ associated with MCDA tools was used. Research development was supported by the following MCDA techniques: Delphi, Boolean, Analytical Hierarchy Process (AHP), and weighted linear combination to analyze criteria related to the spatial problem. The choices of these tools were due to the difference between the criteria and the need for convergence among them, but also to reduce subjectivity during decision-making to indicate potentially suitable areas (Biju, 2015).

The selected assessment criteria must be measurable - spatialized - and have compatible formats, so that they can be processed together in the GIS environment. The criteria used to indicate potentially suitable areas were defined according to the Brazilian Standard No. 15.113/2004 (ABNT, 2004). This standard establishes the basic requirements and criteria for CDW landfill site selection, which is the main objective of this research. Moreover, this standard is in accordance with the Brazilian regulation for waste management, such as The National Policy of Solid Waste - Law No. 12.305 of 2010 and CONAMA resolution No. 307 of $2003-$ National Environmental Council (Brasil, 2002, 2010). Therefore, the criteria selected, which were based on the mentioned standard, are: Distance from urban centers; Water resources; Road distances; Land use and land cover; Zoning; Soil classes; Geology; Slope and; Environmental protection areas. Some criteria require more than one set of geospatial data to be analyzed in the GIS and comply with different legislations, as observed in Table 1.

After criteria selection, inadequate parcels of the study area needed to be excluded, e.g., water bodies, protected areas, urban areas. Moreover, Geus et al. (2019) state that the adequacy models with Boolean overlapping are useful, for example, to eliminate environmental protection areas, parks, and squares, 30-meter strips on both sides of urban streams and rivers, or even places subject to landslides or floods. The GIS technique allowed a logical operator (Boolean) to be used to carry out intersections between the layers of geographic data, represented by the selected criteria and their respective restrictions. Therefore, the study performed the logical operations of types A and B, resulting in all elements contained in the intersection between A and B. Mitchell (2012) describes the Boolean adequacy model as one of the most used models to assess areas for a particular use. According to him, this type of adequacy model divides a site into two distinct groups or sets: those that are 
adequate (value 1 ) and those that are not (value 0 ). The model assesses whether each site meets each criterion. The answer must be "yes" (value 1) for all criteria assigned so that a site can be included in the set of suitable places. The benefit of the Boolean approach is its simplicity and easy application, with a logical combination of maps, in a GIS environment directly analogous to the traditional method of overlapping employed in light tables. Thus, a map for constrained/not suitable areas was created.

Also, it may not be appropriate to treat each of the combined criteria as equally important (Câmara, 1995). Usually, criteria have different levels of importance, which may hinder the decision process difficult. That is why it is necessary to define which of these criteria have a greater degree of importance in accordance with the decision-makers' view. According to Malczewski (1999), these difficulties can be reduced when all the criteria are standardized and classified through weighting assignment. For this reason, this study decided to draft and send a questionnaire based on Delphi techniques associated with the AHP to several experts on the subject. The questionnaire is intended to facilitate formal discussion among experts, especially when they cannot get together in one place (Wakefield and Watson, 2014). According to Gupta and Clarke (1996), this method aims to reach the most reliable consensus in a group of experts through a series of questionnaires interspersed with feedback. The Delphi process is characterized by a set of surveys and it is necessary to have two to three rounds of questionnaires. This technique is widely used to access expert's opinion and to enhance clarity of the subject (Page et al., 2021).

As stated before, combined criteria should not be handled equally. In fact, to reduce bias, criteria must be standardized and prioritized. MCDA aims to structure, design, and assess decisions according to the stakeholders' views, and to transform this into a decision. Therefore, the AHP method developed by Saaty (1987) was chosen because the method is intended to assist the decision-making process based on qualitative and quantitative criteria, aiming to analyze the expert's judgment in the decision process, transforming complex problems into simpler ones by decision hierarchy. The AHP consists of a pairwise comparison, followed by the construction of a comparison matrix on a fundamental scale from 1 to 9 to rank the selected criteria (Saaty, 1990). Moreover, the AHP is widely used in environmental decision-making (Görener et al., 2012), which demonstrates that AHP is a methodology that fits the purpose of this research.

Therefore, a survey was designed according to the Delphi method, two rounds of questionnaires were sent to a set of experts, who were chosen due to their expertise in CDW management. As the minimal number of experts required by the method is 10 , an invitation to

Table 1 - Sources of spatial data and normative references used.

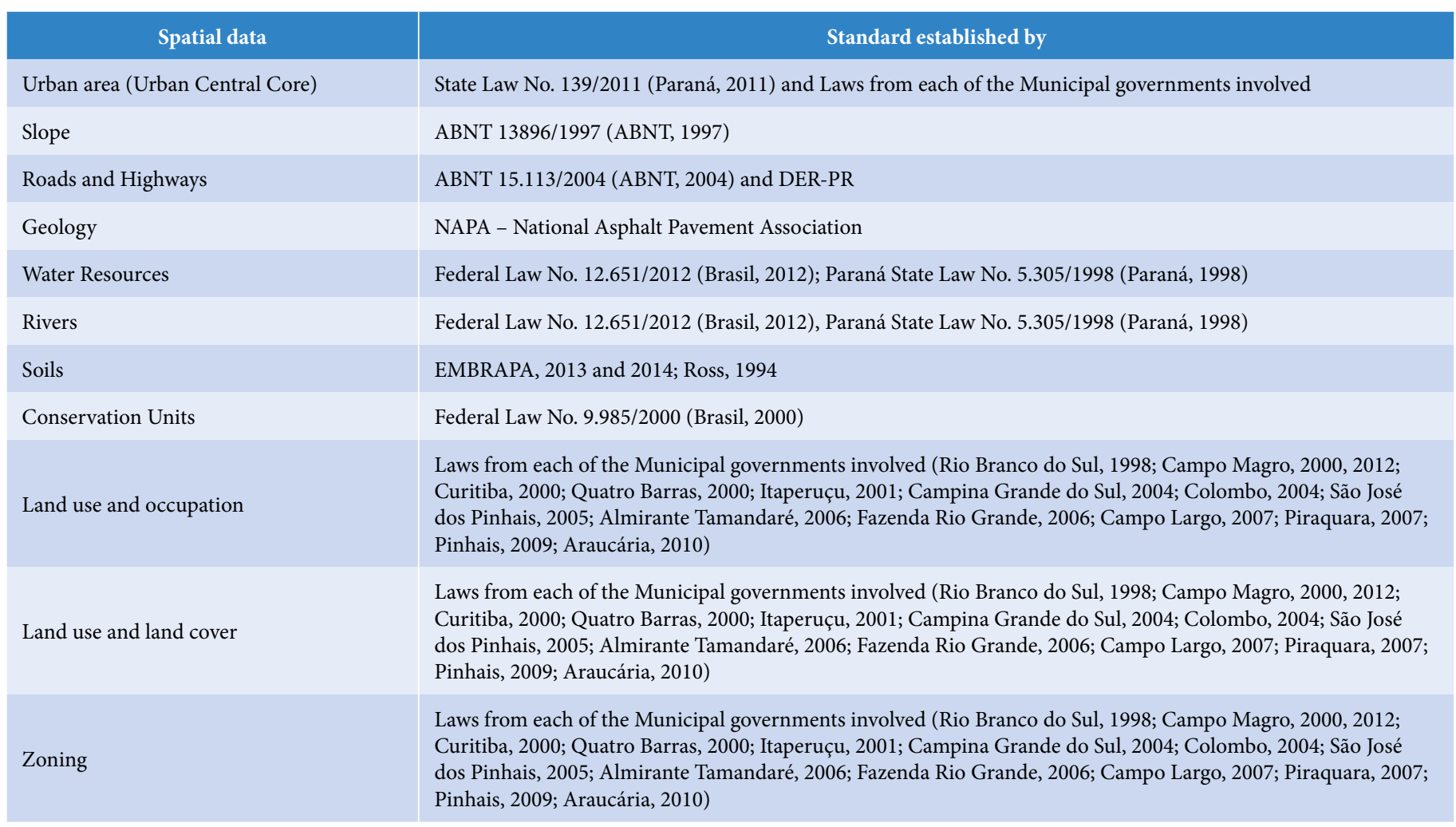


answer our survey was sent to 26 experts with relevant expertise in the area. In these questionnaires, the AHP technique was applied to compare, rank, and standardize the criteria. Also, there was an open question within the survey, where the experts could suggest changes in the set of criteria. After that, the first round of responses of the pairwise comparison was processed, and the criteria were normalized and staggered. Moreover, according to the experts, the criteria were enough and in accordance with the purpose of this research.

While the first round of questionnaire responses was processed in Expert Choice, the geographic data in vector format of the criteria were converted into raster data in a GIS (ArcGIS ${ }^{\circledR}$ ) environment, whose objective is to create adequacy maps from algebra calculations between variables. Subsequently, all raster data were standardized (reclassified) on a common scale from 1 to 5 , with 1 being the least adequate and 5 being the most adequate. According to Esri (2015) resources, reclassification is considered an adequacy model done by assigning values of preference, sensitivity, priority, or similarity, thus creating a common scale of values. After response processing, the second round was sent to experts within the feedback responses, and another open question was sent to verify if they agreed with the results of the analysis.

For the criterion "Distance from the urban center", the study considered a buffer with intermediate values, starting with 1 (less suitable) as 100 meters, 2 as 200 meters, 3 as 300 meters, 4 as 400 meters, and 5 and above as 500 meters (more suitable). From 200 meters onwards, suitability increases since areas around urban centers are less suitable. The study chose the values according to the municipal laws (land use and zoning law) of the 14 cities studied. Based on the criterion "Distance from highways and roads" and according to Associação Brasileira de Normas Técnicas (ABNT) 15.113 (ABNT, 2004), a landfill should not be located too far from highways, streets, and roads. In fact, the same rule defines the minimum distance between roads and the selected area. According to the Department of Roads and Transportation of the State of Paraná, the extent of disused areas is 15 meters, but there is still the field range of the highway, and it can reach 70 meters on both sides of the highway (DER-PR, 2012). Therefore, the study created a multiple buffer of roads and highways with the following distances: 100 meters, 200 meters, 250 meters, 300 meters, and 350 meters. Considering that 250 meters is an intermediate value (not near and not far from the main roads), it is considered the best distance (value 5). The greater the distance, the less suitable the area is; the distance of 350 meters was reclassified as 2, and distances above this value were reclassified as 1 . Distances lower than 100 meters were constrained using Boolean operator, since these areas were not suitable.

The land use and occupation criterion for assigning pre-defined values was based on each city's zoning laws. In many municipalities, protected areas, such as parks, reserves, conservation units, and other areas, are already included in their zoning map. Therefore, these pro- tected areas were classified as restricted, being assigned value 0 . Values from 2 to 4 were assigned according to the zoning regulation. In some municipalities, industrial and/or rural areas were assigned value 5 (more suitable). Moreover, in some municipalities, this type of work implantation is allowed in their industrial and rural areas, so value 5 was assigned to both places.

Soils were reclassified according to their fragility: 1 (less suitable) for Gleysols and 5 (more suitable) for Latosols, according to the Brazilian Agricultural Research Corporation (Embrapa Solos, 2013) and Ross (1994). Geologically, value 1 was assigned to sedimentary rocks and value 5 to igneous rocks, according to the mechanical resistance of rocks, defined by the report "Hot Mix Asphalt Materials, Mixture, Design, and Construction" published by NAPA. The geotechnical criteria, generated from various spatial data, refer to a set of factors related to the susceptibility of a site, such as erosion susceptibility. In this case, water, slope, and geology data integrated this factor to scale, hence all data were compiled and the suitable areas were defined considering the geotechnical criterion. Slopes between 1 and $30 \%$ of the study area were considered the most appropriate (value 5), that is, the higher the slope, the lower the adequacy. The values were based on the Brazilian Landfill Standard ABNT 13896/1997. In addition, in restricted areas protected by law (for example, parks and watercourses), a 100-meter buffer was established for these areas (value 1), considering that the greater the distance, the greater the site adequacy. In some cities of the Urban Central Core, such as Curitiba, minimum distances from rivers vary, as defined by the Special Sector of Health, Environment, and Conservation, specified in the law of land use and occupation. However, there are also different distances established in Federal Law No. 12.651/2012. A 400-meter buffer for water resources was defined as an intermediate value between those described in the Federal Law; thus, the greater the distance, the greater the area adequacy.

To verify area adequacy according to the proposed objective, a map was prepared with all data previously reclassified, integrated, and analyzed. The output data was the final suitability map of the study case. After prioritizing the criteria defined by the results from the first round of the Delphi questionnaire, along with previously treated geographic data, this study determined the Equation 1 and the weighted linear combination that could compose the final map. According to Estoque (2011), it is the most used equation for MCDA. ArcGIS ${ }^{\circledR}$ has a tool based on Equation 1, called Weighted Overlapping, which was used to assign weights to the criteria, with subsequent multiplication among them, as recommended by Equation 1 .

$S=\sum W i X i \times \Pi C j$

Where:

$\mathrm{S}=$ area suitability;

$\mathrm{X}_{\mathrm{i}}=$ staggered factors; 
$\mathrm{W}_{\mathrm{i}}=$ weights assigned to each criterion;

$\mathrm{C}_{\mathrm{j}}=$ restrictions (or Boolean factors),

$\Sigma=$ sum of weighted factors;

$\Pi=$ restriction product $(1-$ suitable, 0 - constrained $)$.

In the following step and based on Equation 1, the map of constrained areas is multiplied by the suitability map, using Map Algebra in ArcGIS. With the output data, a map was generated to indicate potentially suitable areas for CDW waste disposal. For the area to be considered adequate, its size must be at least $12,000 \mathrm{~m}^{2}$. This value was determined from a literature review on CDW landfills, based on the estimated population of the Metropolitan Area of Curitiba and the CDW data obtained from the ABRELPE (2014) survey. Using the data extracted from ABRELPE (2014) report and the population of the Metropolitan Area of Curitiba - 3,223,836 inhabitants, according to the Brazilian census (IBGE, 2010) - this study estimated the total CDW generated daily in the Urban Central Area, resulting in less than 200 tons/week. This would be close to what happens in New York, where CDW landfills with $12,000 \mathrm{~m}^{2}$ (about 3 acres) or less can receive up to 200 tons per week (New York State, 1989).

As a result, the study created the final map, indicating potentially suitable areas for CDW disposal. Two areas located in the municipality of São José dos Pinhais were chosen by the authors for an on-site visit to verify whether the areas were suitable - according to criteria established — for a landfill, validating the agreement between data output and the proposed methodology. São José dos Pinhais municipality was selected because it is close to Curitiba and has many potentially suitable areas. Nevertheless, the objective of this research was not to define a specific area, but to indicate suitable areas in the Urban Central Core of Curitiba.

\section{Study area}

The study area is the Urban Central Core of Curitiba, in the State of Paraná, Brazil. The determination of this area (Figure 1) - which contains 14 municipalities - considered the integrated relations of municipalities, such as commercial and employment relationship, and high population density. Additionally, the capital of the state of Paraná, Curitiba, is inserted in this area.

\section{Results and Discussion}

To design the map of constrained areas, the areas were divided into two classes - suitable and unsuitable. The creation of a Buffer, in combination with the "Is Null" operation, plus the Raster Calculator tool with GIS usage, allowed the areas to be classified as suitable and unsuitable. According to Malczewski and Rinner (2015), the approach operation (Buffer) generates limits around objects, having the same distance in all directions, thus resulting in a binary buffer, where the inner area inside this limit is assigned a value equal to zero $(0)$ and the remaining areas, a value equal to 1 . Within the areas considered to be unsuitable ( 0 ) (Figure 2), there were water resources, protected areas, and streets/roads, showing that GIS was effective in excluding these areas. Following the procedure described in Chang et al. (2008), the first landfill implementation analysis was effective, excluding sensitive areas, while maintaining suitable areas for further assessment.

The design of suitable maps, as in most multi-criteria decision-making methodologies, requires criteria to be weighted. Then, the criteria map must be standardized for an analysis to be performed (Demesouka et al., 2019). Subsequently, the group of experts answered a two-round questionnaire and returned it, allowing Delphi method validation. The "core" of the Delphi method is its structure, which lists all con-
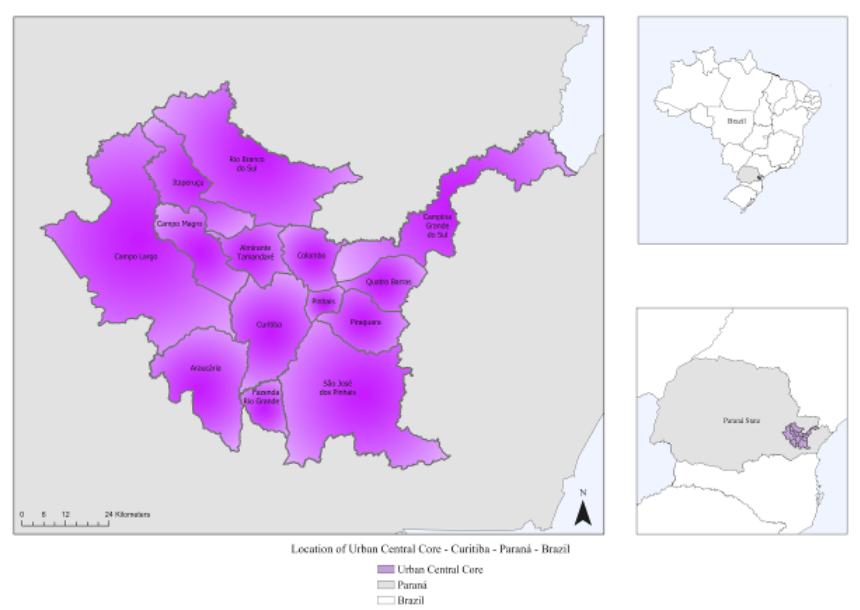

Figure 1 - Location of the Urban Central Core of the Metropolitan Area of Curitiba.

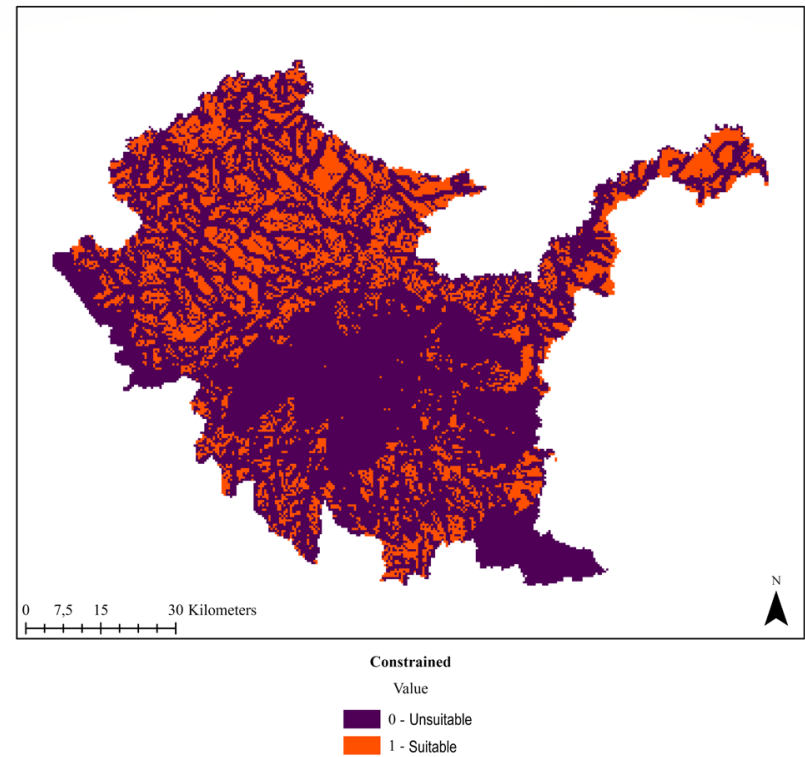

Figure 2 - Constrained areas for the Urban Central Core. 
tributions made by individuals who offer a perspective or view of the group. For this reason, this technique is feasible for the decisions made (Malczewski, 1999). Software "Expert Choice" performed the analysis of the first round of questionnaires, in which the criteria were hierarchized reducing data analysis time. As observed in Figure 3, weight was also assigned to the criteria. They were ranked from 0 to 1 according to the AHP method, in which distance from water resources and vegetation (green areas) was considered the most important criterion to be considered during site selection. These results were sent to experts, in a second round of questionnaires, in accordance with the method proposed. Most of the experts agreed with the result, only one did not approve it completely. However, the expert disagreed with the criterion 'vegetation' having higher importance - for other experts - than soil, not with the 'water resources' criterion. More importantly, the inconsistency level of a pairwise comparison according to Saaty (1987) should be lower than $10 \%$, and in our survey, inconsistency was $2 \%$, meaning that we did not need to contact the expert again and repeat the survey.

After area adequacy escalation for each criterion was completed, the suitability map was prepared by multiplying the criteria among themselves. Moreover, to assign the weights defined by the experts for each criterion through the Delphi questionnaire responses, the operation Weighted Overlay in a GIS environment was used to create the final suitability map (Figure 4). This tool facilitates data compilation because, in addition to assigning weights to the criteria, the user can also classify (if the map is not reclassified) the criteria before performing the spatial analysis (Esri, 2015). Another advantage is that the tool does not work if the user does not assign the weights; this reduces the chances of errors in the algebra map implementation.

Subsequently, the constrained and suitability maps were multiplied, by using Map Algebra "Times" tool, resulting in the constrained and suitable area map where areas were classified from 1 (constrained/ lowest suitability) to 5 (highest suitability) (Figure 5).

After the map of constrained and suitable areas was designed, the minimum size of $12,000 \mathrm{~m}^{2}$ for the landfill area (approximately 3 acres) was delimited. Meaning that any area greater than this value was used to indicate the most suitable areas; this identification was made in GIS software, with the use of the 'Set Null' operation for all other values. Then, using the spatial data of the constrained and suitable areas output, classes lower than 5 were excluded and defined in GIS software as "No Data", resulting only in potentially suitable areas with the highest value, fulfilling the main objective of the study. Suitable areas are shown on the map as "potentially suitable areas" (Figure 6). Areas with a value equal to 5 (more suitable) are rural or industrial areas, according to the city's zoning law. Not all rural areas of the Urban Central Core can be used for this type of project, like sites located in the Karst aquifer area, in the city of Almirante Tamandaré, Paraná.

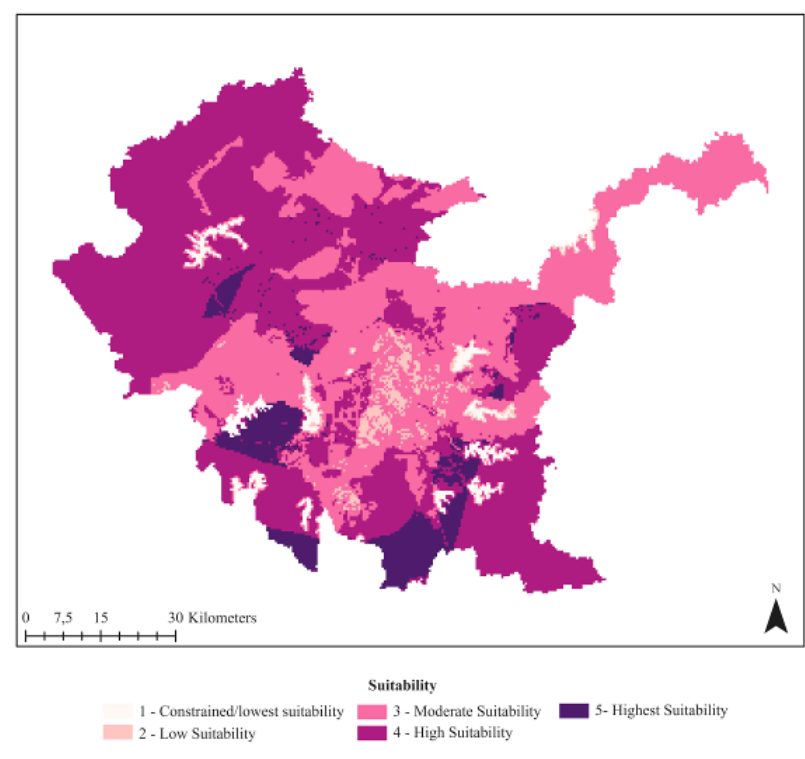

Figure 4 - Suitability map of the Urban Central Core.

\section{Distance from Water Resources Distance from Roads and Highways \\ Soils \\ Vegetation \\ Geotechnics \\ Distance from Urban Center Land use and occupation Slope}

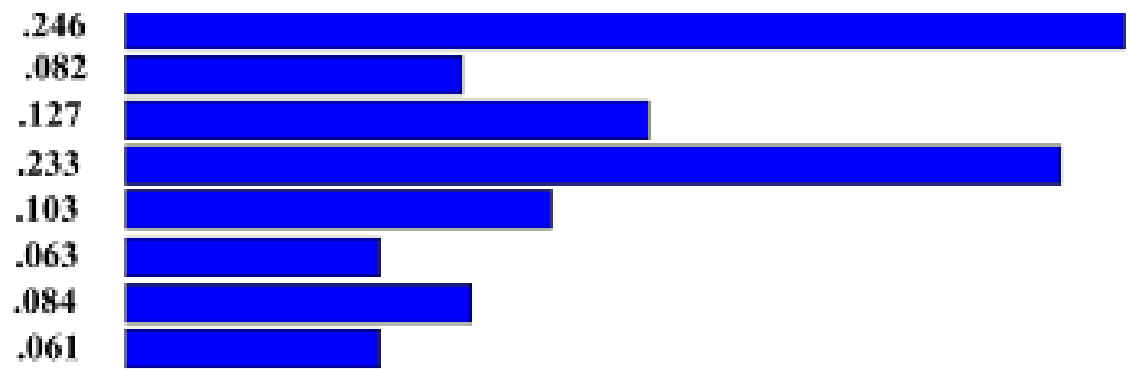

Inconsistencv $=0.02$ with 0 missine iudements

Figure 3 - Questionnaire Responses: weighted and hierarchized criteria for site selection. 


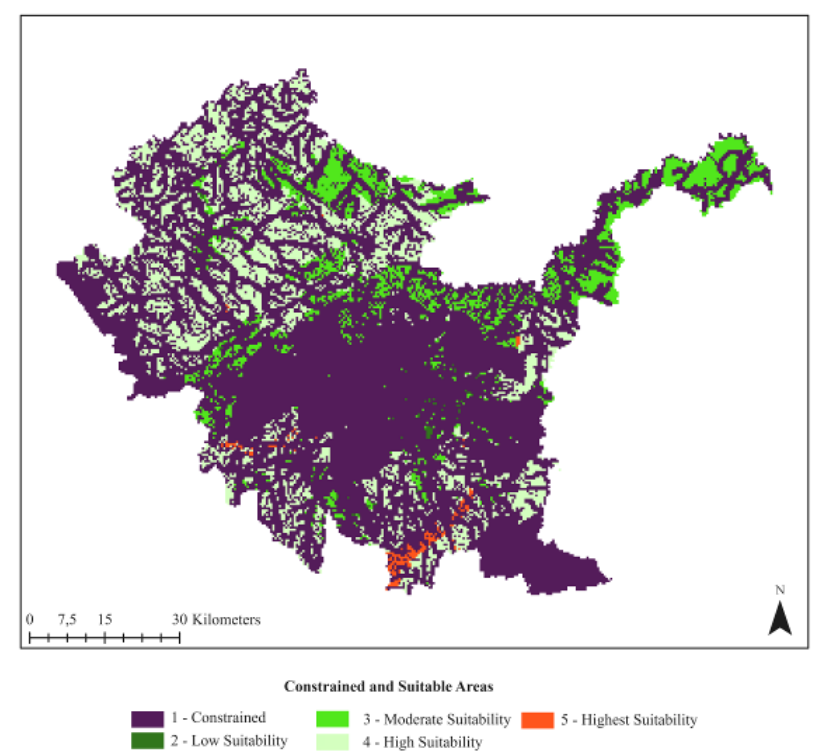

Figure 5 - Final suitability map.

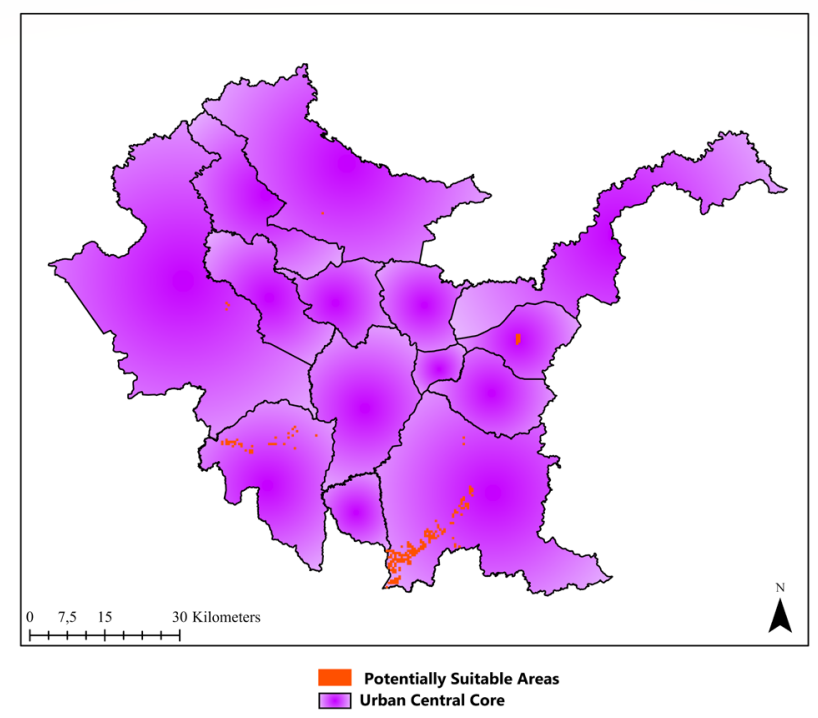

Figure 6 - Map of potentially suitable areas for landfill class A deployment.

As it can be noted, most of the areas are located in the municipality of São José dos Pinhais, some in Araucária, while others are more widespread throughout the Urban Central Core. According to the municipal zoning law of many municipalities, occupation of some protected areas is restricted, e.g., the city of Campina Grande do Sul,

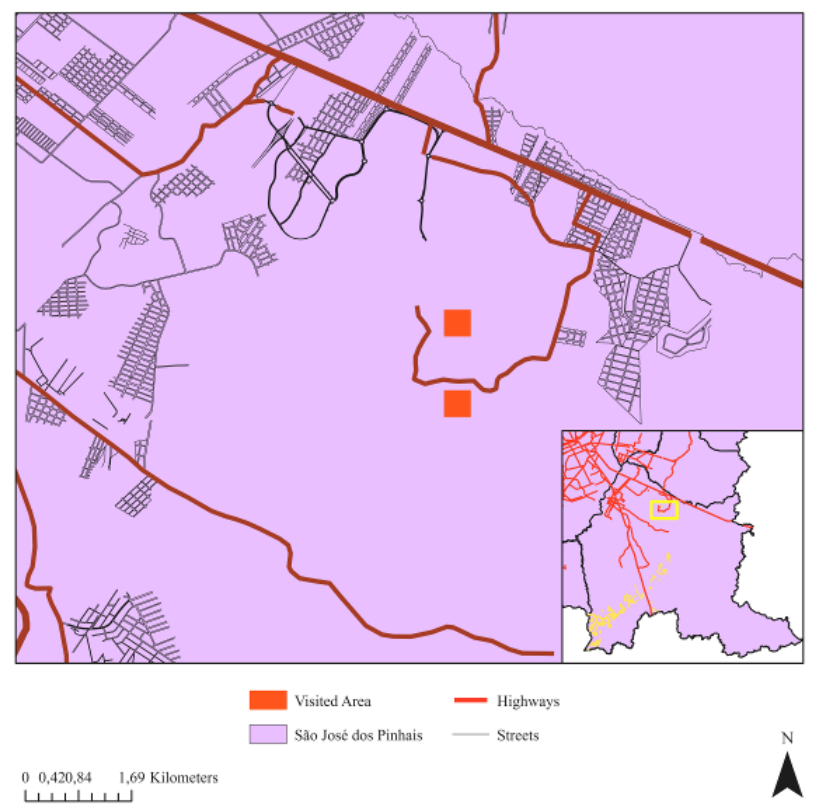

Figure 7 - Area location for on-site observation.

where most of the area is constrained, and land use and occupation are controlled. The municipalities of São José dos Pinhais and Araucária have extensive industrial and rural areas and, consequently, have a larger number of suitable areas. In addition, access to these two municipalities occurs through federal and state highways, facilitating access to certain areas of the municipalities. However, a verification through on-site observation to confirm the findings and verify methodology adequacy was conducted only in two areas located in São José dos Pinhais (Figure 7). Visiting all areas would be costly and time-consuming, especially in places where access is difficult due to different factors, i.e., unpaved roads, privates areas, distance, etc. Additionally, these areas were chosen mainly because of their proximity to the State Capital and are located in an area known for its high concentration of industries, an important place for the metropolitan region of Curitiba.

On-site observation was carried by the authors only to verify if the methodology was adequate to the main objective of this research, that is, indicate potentially suitable areas for a Class A landfill, and not to choose adequate sites. During on-site observation, the authors identified some interesting characteristics in these areas. For instance, the areas are close to BR-277 highway, which facilitates access to construction and demolition waste disposal locations. They are predominantly rural areas, occupied by country houses, with small-cultivated areas. There are some residences nearby, located at a safe distance from the indicated areas. In "area 01 ", access is via a partially paved road; the area has a small portion of planted forest and has no steep relief. In the second location, called "area 02 ", there is no steep relief; access occurs through an unpaved road up to a certain point and then 
through a paved road. After that, road access is reduced, but this can be modified. The area is also private, with little to no vegetation, with only agricultural areas of low commercial value. After all, the chosen sites (in relation to the adopted criteria) agree with the analysis previously performed in the GIS environment and show how this tool supported by the MCDA technique can be very useful in solving decision-making problems where a geographical component is of great importance.

\section{Conclusion}

The greatest difficulty during the study was obtaining spatial data for the criteria established for the study area. Insufficient data may limit GIS application at different stages of solid waste management. However, it was feasible to evaluate the study area, despite the existence of some limitations. During an on-site visit, it was possible to verify the importance of GIS software to organize, process, and analyze geographic data, and to create maps indicating potentially suitable areas. Both the GIS and the MCDA method were efficient in restricting, prioritizing, and weighting spatial data, helping reduce subjectivity and uncertainties related to data integration and criteria analysis, as well as considering those selected by the decision-makers. CDW landfills should be implemented to reduce environmental impacts and protect human health. According to the Brazilian legislation, this type of land- fill should be used for material storage and future use, including the future use of the area, rather than just disposing of waste in landfills, reducing its useful life. Therefore, the correct indication of suitable areas for this purpose must be made considering these aspects, especially in developing countries, where this type of waste is a significant environmental issue.

Additionally, the main point of this study was to indicate potentially suitable areas rather than select them. Other relevant information on landfill location, including standards and installation, should also be considered if the selection of an appropriate site was to be performed. Then, further studies are required to select one of the areas for the disposal of construction and demolition waste. Furthermore, private companies and government agencies can use the proposed methodology for integrated waste management - not only for the municipalities covered by the study case. If adapted accordingly, the proposed method can be applied in other locations. Moreover, it can not only be used to indicate potentially suitable areas for Class A landfills, but also for landfills of other categories. Ultimately, it can be adapted and implemented in other stages of solid waste management, especially when the objective is to reduce costs, time, and social and environmental impacts arising from illegal solid waste disposal.

\section{Contribution of authors:}

Biju, B.P.: Conceptualization, Methodology, Validation, Formal Analysis, Investigation, Resources, Data Curation, Writing - Original Draft. Nagalli, A.: Conceptualization, Validation, Supervision, Project Administration. Moura, E.N.: Conceptualization, Methodology, Software, Validation, Supervision, Writing - Review \& Editing.

\section{References}

Almirante Tamandaré. 2006. Lei Complementar n²/2006. Dispõe sobre o Código de Zoneamento de Uso e Ocupação do Solo do Município de Almirante Tamandaré (Accessed April 12, 2014) at: https://leismunicipais.com. br/plano-de-zoneamento-uso-e-ocupacao-do-solo-almirante-tamandare-pr.

Araucária. 2010. Lei n 2.160/2010. Dispõe sobre o zoneamento, o uso e a ocupação o solo do município de araucária e dá outras providências. (Accessed April 12, 2014) at: http://leismunicipa.is/chljg.

Associação Brasileira de Empresas de Limpeza Pública e Resíduos Especiais ABRELPE. 2014. Panorama dos resíduos sólidos no Brasil. ABRELPE, São Paulo.

Associação Brasileira de Normas Técnicas - ABNT. 1997. NBR 13896 - Aterros de resíduos não perigosos - critérios para projeto, implantação e operação. ABNT, Rio de Janeiro, 12 p.

Associação Brasileira de Normas Técnicas - ABNT. 2004. NBR 15113 Resíduos sólidos da construção civil e resíduos inertes - aterros - diretrizes para projeto, implantação e operação (Accessed April 15, 2015) at: https:// www.abntcatalogo.com.br/norma.aspx?ID=347.
Biju, B.P., 2015. Utilização do sistema de informação geográfica (SIG) na indicação de possíveis áreas aptas à disposição de resíduos de construção e de demolição. Dissertação de Mestrado, Programa de Pós-Graduação em Engenharia Civil, Universidade Tecnológica Federal do Paraná, Curitiba.

Boroushaki, S.; Malczewski, J., 2008. Implementing an extension of the analytical hierarchy process using ordered weighted averaging operators with fuzzy quantifiers in ArcGIS. Computers and Geosciences, v. 34, (4), 399-410. https://doi.org/10.1016/j.cageo.2007.04.003.

Brasil. 2000. Sistema Nacional de Unidades de Conservação. Lei no 9.985 de 18 de julho de 2000. Diário Oficial da União.

Brasil. 2010. Lei da Política Nacional dos Resíduos Sólidos. Lei no 12.305, de 2 de agosto de 2010. Brasília, Diário Oficial da União (Accessed October 1, 2013) at: http://www.planalto.gov.br/ccivil_03/_ato2007-2010/2010/lei/112305.htm

Brasil. 2012. Federal Law no. 12.651, 2012. Dispõe sobre a proteção da vegetação nativa (Accessed April 15, 2015) at: http://www.planalto.gov.br/ ccivil_03/_Ato2011-2014/2012/Lei/L12651.htm. 
Brasil. Conselho Nacional do Meio Ambiente - CONAMA. 2002. Resolution 307. Established directives, guidelines and procedures for the management of construction waste. Ministry of Environment, Brazil (Accessed April 15, 2015) at: http://www.mma.gov.br/port/conama/legiabre. cfm?codlegi $=307$.

Câmara, G., 1995. Modelos, linguagens e arquiteturas para bancos de dados geográficos. Doctoral Thesis, Instituto Nacional de Pesquisas Espaciais, São José dos Campos (Accessed April 15, 2015) at: https://www.researchgate.net/ publication/43653652.

Campina Grande do Sul. 2004. Lei no 51/2004. Institui as normas de uso e ocupação do solo no município de Campina Grande do Sul, e dá outras providências (Accessed April 12, 2014) at: http://leismunicipa.is/cimhn.

Campo Largo. 2007. Lei no 1.963/2007. Dispõe sobre o zoneamento, uso e ocupação do solo no município de Campo Largo, conforme especifica (Accessed April 12, 2014) at: http://leismunicipa.is/bikoa.

Campo Magro. 2000. Lei n ${ }^{\circ}$ 127/2000. Dispõe sobre o zoneamento na Unidade Territorial de Planejamento - UTP de Campo Magro e dá outras providências (Accessed April 12, 2014) at: http://leismunicipa.is/nrtuv.

Campo Magro. 2012. Lei no 731/2012. Dispõe sobre o zoneamento do uso e de ocupação do solo do perímetro urbano da sede, do distrito de retiro, do distrito Conceição do município de Campo Magro e da outra providência (Accessed April 12, 2014) at: http://leismunicipa.is/vsqbu.

Chang, N.-B.; Parvathinathan, G.; Breeden, J.B., 2008. Combining GIS with fuzzy multicriteria decision-making for landfill siting in a fast-growing urban region. Journal of Environmental Management, v. 87, (1), 139-153. https://doi. org/10.1016/j.jenvman.2007.01.011.

Colombo. 2004. Lei no 877/2004. Institui as normas de uso e ocupação do solo no município de Colombo, estado do Paraná, e dá outras providências (Accessed April 12, 2014) at: http://leismunicipa.is/cegdp.

Costa, R.; Silva, G., 2011. Avaliação da qualidade ambiental do aterro sanitário de Caldas Novas (GO). Brazilian Journal of Environmental Sciences (Online), (22), 1-10 (Accessed April 15, 2015) at: http://www.rbciamb.com.br/index. php/Publicacoes_RBCIAMB/article/view/334.

Curitiba. 2000. Lei no 9800/2000. Dispõe sobre o zoneamento, uso e ocupação do solo no município de Curitiba, revoga as leis no 4199/72, 5234/75, 5263/75, 5490/76, 6204/81, 6769/85, 7068/87 e 7622/91, e dá outras providências (Accessed April 12, 2014) at: http://leismunicipa.is/dncpe.

Dalmas, F.B.; Goveia, S.S.; Oliveira, F.R.; Amaral, C.H.; Macedo, A.B., 2011. Geoprocessamento aplicado à gestão de resíduos sólidos na ugrhi-11-ribeira de iguape e litoral sul. Geociências, v. 30 (Accessed April 17, 2015) at: http:// www.ppegeo.igc.usp.br/index.php/GEOSP/article/view/7200.

Demesouka, O.E.; Anagnostopoulos, K.P.; Siskos, E., 2019. Spatial multicriteria decision support for robust land-use suitability: the case of landfill site selection in Northestern Greece. European Journal of Operational Research, v. 272, (2), 574-586. https://doi.org/10.1016/J.EJOR.2018.07.005.

Demesouka, O.E.; Vavatsikos, A.P.; Anagnostopoulos, K.P., 2013. Suitability analysis for siting MSW landfills and its multicriteria spatial decision support system: method, implementation and case study. Waste Management, 33, (5), 1190-1206. https://doi.org/10.1016/j.wasman.2013.01.030.

Departamento de Estradas e Rodovias do Estado do Paraná - DER-PR. 2012. Manual de orientação o uso e ocupação faixa de domínio. DER-PR, Curitiba (Accessed April 16, 2015) at: https://www.caminhosdoparana.com.br/site2015/ wp-content/uploads/2015/08/manualorientacao.pdf.

Empresa Brasileira de Pesquisa Agropecuária (Embrapa) (Ed.). 2013.

Sistema Brasileiro de Classificação de Solos. 3. ed. Embrapa, Brasília, 353 pp. (Accessed December 12, 2014) at: http://livimagens.sct.embrapa.br/ amostras/00053080.pdf.

Esri. 2015. ArcGIS resources. ArcGIS 10.3 help. (Accessed April 16, 2015) at: http://resources.arcgis.com/en/help/.

Estoque, R.C., 2011. GIS-based multi-criteria decision analysis (in natural resource management). D1-Division of Spatial Information Science, University of Tsukuba.

Fazenda Rio Grande. 2006. Lei complementar nº 6/2006. Dispõe sobre o zoneamento de uso e ocupação do solo urbano do município de fazenda rio grande e dá outras providências. (Accessed April 12, 2014) at: http:// leismunicipa.is/mpojc.

Ferreira, M.V.G.; Pinto, J.C., 2010. Destinação final dos resíduos produzidos em obras da construção civil na cidade de Salvador. Salvador.

Geneletti, D., 2010. Combining stakeholder analysis and spatial multicriteria evaluation to select and rank inert landfill sites. Waste Management, v. 30, (2), 328-337. https://doi.org/10.1016/j.wasman.2009.09.039.

Geus, L.M.; Moura, E.N.; Garcias, C.M. 2019. Uso do SIG como suporte à definição da localização de pontos de entrega voluntária de resíduos de construção e demolição. Tecnologia e Sociedade, v. 15, (37), 23-39. https://doi. org/10.3895/rts.v15n37.7703.

Görener, A.; Toker, K.; Uluçay, K. 2012. Application of combined SWOT and AHP: a case study for a manufacturing firm. Procedia - Social and Behavioral Sciences, v. 58, 1525-1534. https://doi.org/10.1016/j.sbspro.2012.09.1139.

Gupta, U.G.; Clarke, R.E., 1996. Theory and applications of the Delphi technique: a bibliography (1975-1994). Technological Forecasting and Social Change, v. 53, (2), 185-211. https://doi.org/10.1016/S0040-1625(96)00094-7.

Instituto Brasileiro de Geografia e Estatística - IBGE. 2010. Censo demográfico do Brasil. IBGE, Brasília (Accessed February 11, 2016) at: https:// censo2010.ibge.gov.br/resultados.html.

Itaperuçu. 2001. Lei no 151/2001. Dispõe sobre alteração do zoneamento urbano municipal, alterando também a Lei 16/1993. (Accessed April 12, 2014) at: http://leismunicipa.is/rpkua.

Koc-San, D.; San, B.T.; Bakis, V.; Helvaci, M.; Eker, Z., 2013. Multi-criteria decision analysis integrated with gis and remote sensing for astronomical observatory site selection in Antalya Province, Turkey. Advances in Space Research, v. 52, (1), 39-51. https://doi.org/10.1016/j.asr.2013.03.001.

Malczewski, J., 1999. GIS and multicriteria decision analysis. John Wiley \& Sons, Ontario.

Malczewski, J., Rinner, C., 2015. Introduction to GIS-MCDA. In: Multicriteria decision analysis in geographic information science. Springer, Berlin, pp. 23 54. https://doi.org/https://doi.org/10.1007/978-3-540-74757-4_2.

Mitchell, A., 2012. The Esri guide to GIS analysis, Volume 3: modeling suitability, movement, and interaction. Esri Press (Accessed July 21, 2015) at: https://esripress.esri.com/display/index. $\mathrm{cfm} ?$ fuseaction $=$ display\&websiteID $=215 \&$ moduleID $=0$.

New York State. Department of Environmental Conservation. 1989. Construction \& demolition debris landfill enforcement policy. Department of Environmental Conservation, New York (Accessed July 22, 2015) at: https:// www.dec.ny.gov/regulations/25230.html.

Page, M.J.; McKenzie, J.E.; Bossuyt, P.M.; Boutron, I.; Hoffmann, T.C.; Mulrow, C.D.; Shamseer, L.; Tetzlaff, J.M.; Moher, D., 2021. Updating guidance for reporting systematic reviews: development of the PRISMA 2020 Statement. Journal of Clinical Epidemiology, v. 134, 103-112. https://doi.org/10.1016/j. jclinepi.2021.02.003. 
Paraná. 1998. Gerenciamento integrado para proteção dos mananciais da região metropolitana de Curitiba. Lei no 5.305 de 1998. Gazeta Oficial do Estado (Accessed July 3, 2014) at: http://www.imprensaoficial.pr.gov.br/.

Paraná (Estado). 2011. Lei Complementar no 139, de 9 de dezembro de 2011. Altera o Parágrafo Único do Art. $2^{\circ}$, da Lei no 11.027, de 29 de dezembro de 1994, (Comec), incluindo os municípios de Piên, Campo do Tenente e Rio Negro. Curitiba (Accessed April 12, 2014) at: https://www.legislacao.pr.gov.br/legislacao/exibirAto. do?action $=$ iniciarProcesso\&codAto $=62625 \&$ codItemAto $=477612$.

Pinhais. 2009. Lei no 1031/2009. Dispõe sobre o zoneamento, o uso e a ocupação do solo urbano, e novos parâmetros sobre o parcelamento do solo na zona de interesse social que especifica. (Accessed April 12, 2014) at: http:// leismunicipa.is/khgfs.

Pinheiro, L.; Cattanio, J.H.; Imbiriba, B.; Castellon, S.; Elesbão, S.; Ramos, J., 2019. Medidas de fluxo de dióxido de carbono e metano em um depósito de resíduos insalubre na Amazônia. Brazilian Journal of Environmental Sciences (Online), (54), 13-33. https://doi.org/10.5327/Z2176-947820190021.

Piraquara. 2007. Lei no 911/2007. Dispõe sobre o zoneamento do uso e ocupação do solo das áreas urbanas do município de Piraquara, e dá outras providências (Accessed April 12, 2014) at: http://leismunicipa.is/lcsdb.

Quatro Barras. 2000. Lei no 33/2000. Dispõe sobre o zoneamento de uso do solo urbano do município de quatro barras e dá outras providências (Accessed April 12, 2014) at: http://leismunicipa.is/nmsbi.

Ramos, R.A.R., 2000. Localização industrial: um modelo espacial para o noroeste de Portugal. Doctoral Thesis, Universidade do Minho, Braga (Accessed May 15, 2015) at: http://repositorium.sdum.uminho.pt/ handle/1822/184.
Rikalovic, A.; Cosic, I.; Lazarevic, D., 2014. GIS based multi-criteria analysis for industrial site selection. Procedia Engineering, v. 69, 1054-1063. https://doi org/10.1016/j.proeng.2014.03.090.

Rio Branco do Sul. 1998. Lei no 482/1998. Dispõe sobre o zoneamento do uso do solo urbano da sede do município de Rio Branco do Sul (Accessed April 12, 2014) at: http://leismunicipa.is/meywk.

Roberts, F.L.; Kandhal, P.S.; Brown, E.R.; Lee, D.Y.; Kennedy, T.W., 1996. Hot mix asphalt materials, mixture, design and construction. 2. ed. National Asphalt Pavement Association Research and Education Foundation, Maryland, $604 \mathrm{p}$.

Ross, J.L.S., 1994. Análise empírica da fragilidade dos ambientes naturais antropizados. Revista do Departamento de Geografia, v. 8, 63-74. https://doi. org/10.7154/rdg.1994.0008.0006.

Saaty, R.W., 1987. The analytic hierarchy process-what it is and how it is used. Mathematical Modelling, v. 9, (3-5), 161-176. https://doi.org/10.1016/02700255(87)90473-8.

Saaty, T.L. 1990. How to make a decision: the analytic hierarchy process. European Journal of Operational Research, v. 48, (1), 9-26. https://doi. org/10.1016/0377-2217(90)90057-I.

São José dos Pinhais. 2005. Lei Complementar no 16/2005. Dispõe sobre o zoneamento, o uso e a ocupação do solo e sistema viário do município de São José dos Pinhais, Estado do Paraná (Accessed April 12, 2014) at: http:// leismunicipa.is/hmlrs.

Wakefield, R.; Watson, T. 2014. A reappraisal of Delphi 2.0 for public relations research. Public Relations Review, v. 40, (3), 577-584. https://doi.org/10.1016/j. pubrev.2013.12.004. 